\title{
A FIATAL LABDARÚGÓK SZEMÉLYISÉGÉT ÉS PÁLYAFUTÁSÁT BEFOLYÁSOLÓ TÉNYEZÖK VIZSGÁLATA A SZÜLŐK ÉS AZ EDZŐK VÉLEMÉNYÉNEK TÜKRÉBEN
}

\author{
KISS ZOLTÁN ${ }^{1}$ - CSÁKI ISTVÁN² - BOGNÁR JÓZSEF \\ ${ }^{1}$ Puskás Ferenc Labdarúgó Akadémia, Felcsút \\ ${ }^{2}$ Eszterházy Károly Egyetem Neveléstudományi Doktori Iskola, Eger \\ ${ }^{3}$ Eszterházy Károly Egyetem Természettudományi Kar, Eger
}

Napjainkban válogatott szinten a magyar utánpótlás labdarúgó csapatok teljesítménye többször megközelíti az európai elit szintjét, ennek ellenére kevés nemzetközi szinten is jegyzett labdarúgó alkotja a felnőtt válogatott keretét. A bentlakásos akadémiai rendszer az elmúlt évtizedben a magyar labdarúgás-utánpótlás képzésének fontos részévé vált. Az akadémiák szabályozott rendszerében a sportszakmán túl pedagógiai hatások is érik a fiatal tehetségeket, így a személyi és tárgyi környezet együttesen járul hozzá a személyiség és jellem alakulásához.

A labdarúgás sportágra vetítve elmondható, hogy kevés azon hazai kutatások száma, mely az edző pedagógiai szerepét vizsgálja (Révész, Bognár, Csáki, \& Trzaskoma-Bicsérdy, 2013). A labdarúgás nívójának emeléséhez mindenekelőtt a fiatal tehetségek tudatos fejlesztésére van szükség, mely folyamatban a pedagógiai elvek is jelentős szerepet játszanak (Csáki, Bognár, Révész \& Géczi, 2013). Az edzőkre pluszfeladatok is hárulnak, melyek közül komoly jelentőséggel bír a szülői gondoskodás és támogatás pótlása.

\section{Elméleti háttér}

A fiatal sportoló tehetségének kibontakoztatásában komoly befolyásoló tényező az edző és a szülő interakciója. Más-más módon, de mindenkinek jut szerep a sportoló karrierjének beteljesülésében (Anshel, 2003).

A gyermekek nevelésének fontossága a társadalmi közgondolkodás terén sem vitatott téma. Zrinszky $(2006,14)$ a következőképpen határozza meg a nevelés eszenciáját: „a nevelés az a tevékenység, mellyel valaki(k) (alapesetben: a felnőttek) úgy kívánnak hatni másokra (alapesetben a felnövekvőkre), hogy azok optimálisan fejlődjenek, megerősödjenek abban, amit nevelőik kívánatosnak tartanak, és maradandóan változzanak meg mindabban, ami nevelőik szerint nem kívánatos.” 
A nevelés folyamatában értékteremtés vagy értékközvetítés történik és maga a nevelési érték az egyén konstruktív életvezetéseként értelmezhető. Számos kutatás támasztja alá, hogy az egyén sajátosságaihoz tartozó erkölcsi magatartás-repertoár megszilárdulása a serdülőkorra tehető. A folyamat sikeressége döntően befolyásolja az egyén életpályájának ívét, így létfontosságúvá válik a pedagógiai intervenció (Bábosik, 2004). Weber idézi Kron (2003) úgy értelmezi a magatartás fogalmát, hogy a hétköznapi valóságot pontosabban ábrázolja a viselkedéssel összevetve, mivel a mindennapokban is érzékelhető történésekre utal és a cselekvők részéről tudatosság tapasztalható.

Tartósan jó sporteredményt elérni csak koncentrált, összeszedett, azaz nevelt személyiség képes, aki az edző által támasztott követelményeknek mindig megpróbál eleget tenni és sportszerü magánélet jellemzi (Gombocz, 2004). Céltudatosság, kitartás és akaraterő hiányában a tehetségek kibontakoztatása nem valósulhat meg az optimális szinten. A jellemfejlesztés fontosságát nem hagyhatja figyelmen kívül az a személy, aki gyerekek tehetségének fejlesztésén fáradozik (Kozéki, 1987).

A különböző nevelési módszerek alkalmazása nagy hatással bír a fiatal sportolók személyiségfejlődésére. Paulsen (1972) szerint olyan területen, ahol nevelési módszereket alkalmaznak és hosszú távon autoritási viszony áll fenn, a szabályszerü tevékenységre és esetlegesen a büntetésre is szükség van.

A szokásformálás nevelési módszerei között található a követelés módszere, melynek segítségével meghatározhatóak azok a magatartás- és tevékenységformák, amelyek szokássá alakítása kijelölésre kerül (Bábosik, 2004). Elsősorban a követelmények, a minta és az értékelés alkalmazásával valósul meg a sportoló normaorienált tevékenységeinek és jellemének alakítása. A labdarúgás bentlakásos akadémiai tehetséggondozás adekvát jellemzője az, hogy a sportolók az elvárt szabályok és normák szerint stabilan viselkednek, és hogy a csoport komplex tevékenységeitől vezet az út a csoportnormák belsővé válásáig (Kozma 1994).

A követelményeknek való megfelelés fontos emberi motívum. Ahol nevelés van, ott követelmények is vannak. A követeléssel tulajdonképpen hozzásegítjük a gyereket ahhoz, hogy ez az alapvető motívuma kielégülhessen. A gyerek egyik leginkább önértékelő büszkesége, ha megfelelhet a követelményeknek (Kozéki, 1983). A követelés meghatározott tevékenység végrehajtására készteti az egyént, fontos ismertetőjegye a cselekvésre indító, aktivizáló jelleg. Kelemen (1984) idézi Lewint, miszerint a fiatal személyiség erkölcsi fejlődését belső ellentmondások viszik előbbre. Ezek az ellentmondások az új követelések és az egyén elért fejlettségi szintjei között feszülnek és egyben késztetik az egyént az újabb erőfeszítésekre, létrehozva a pozitív irányú ellentmondás-túlhaladást.

A sporttevékenység, mint önként vállalt feladatrendszer személyiségfejlesztő hatással bír, azonban önmagában nem elegendő a sportoló teljes emberré válásához. A személyiséget ugyan nem csak a sport területén végzett tevékenység formálja, azonban a sportolás közben 
kialakult pozitív jellemvonások nem tevődnek át automatikusan az élet egyéb területeire (Biróné, 2004). Coubertin, idézi Gombocz (2004) is hasonlóan fogalmaz, miszerint a sportban kialakult erények nem automatikusan és nem minden esetben terjednek át a személyiség teljes tevékenységszférájára. Amennyiben az edző tudatosan közvetíti növendéke számára, hogy a sportolás folyamatában létrejövő pozitív személyiségvonásokat a társadalmi élet különböző területein (pl.: iskola) is érvényesítse, akkor a sport által megerősített pedagógiai impulzust hozhat létre (Biróné, 2004). A sport és a testnevelés pozitív hatásai (pl. önbecsülés, motiváció, együttműködés) transzferálódhatnak az iskolai órákon végzett munkára, a teljesítményekre és a magatartásra (Nagy, 2001).

A gyermekkorban a teljesítmény megjelenése természetes módon az iskolában is megvalósulhat. Az iskolában nyújtott teljesítmény is igényli a kitartás meglétét egy adott tevékenység során. Az iskola mint a teljesítmény lehetőségét magában hordozó helyszín megköveteli a becsületes erőfeszítést, az azonnali örömökről való lemondást a későbbi sikerek érdekében (Kozéki, 1987). A fiatal labdarúgók napi szinten sok időt töltenek el az iskola kötelékében, így a sporttevékenység mellett kiváló terep a sportolók erkölcsi magatartásformáinak a fejlesztésére, mely egyike azon tényezőknek, amelyek hatással bírnak a sportolók beválására.

A gyermek adottságainak kibontakoztatását jelentős mértékben befolyásolja a neveltetése, oktatása, mely már az iskoláskor előtti időszakban az első nevelési színtéren, a családban elkezdődik (Czeizel, 1997). A család fontos tényező a nevelésben, a társadalom egyetemes és nélkülözhetetlen intézménye. Egyetemes, mert majd minden kultúrában megtalálható és nélkülözhetetlen, hiszen az egész társadalom minden szférájában fellelhető (Gombocz, 2010). Kay (2004) műve azt vizsgálja, hogy milyen hatásai vannak a család szerepének a sportban való részvétel alapelveire. A család szerepe különösen is jelentős az elsődleges szocializációban, így a sportszocializációban is, mind a sport gyakorlati támogatásában, mind a sportban történő differenciálás forrásaként. Fügedi és munkatársai (2019) vizsgálatában a kapott eredmények alapján elmondható, hogy a mindennapos sporttevékenység nem elegendő a fiatalok személyiségformálására, magatartásformáinak alakítására, a család, kiemelten pedig a szülők bevonása elengedhetetlen. Bognár, Trzaskoma-Bicsérdy, Révész \& Géczi (2006) kiemelik a szülők szerepét a fiatal sportolók tehetségének kibontakoztatásában, fontos faktorként kezelik a szülők által képviselt értékrendet, mely befolyásoló erővel bír gyerekeik akarati-érzelmi tényezőinek megszilárdításában.

Az edzővel szemben támasztott követelmények közé sorolja Gombocz (2010) a pedagógiai felkészültséget. A pedagógiai tudást többféle rész alkotja, melyben különválik a gyakorlatban megnyilvánuló képesség-összetevő, valamint az elméleti képzettség. A kiemelkedő pedagógiai teoretikus ismeret még nem jelent biztositékot a jó gyakorlati tevékenység megvalósulására. A pedagógiai képességek között megtaláljuk a pedagógiai megfigyelőképességet, képzeletet, emlékezetet és a szervezőkészséget. 
Vannai (2019) szintén kiemeli művében, hogy az edzőnek a sportpedagógia és az erkölcs terén is tudással kell rendelkeznie, nem elég csupán a szakmai ismereteinek tárházát bővíteni.

Tanulmányában Rábai (2018) azt a célt tűzte ki, hogy egy fóvárosi és egy vidéki labdarúgó akadémia tükrében közelebbi képet kapjunk az intézményekben megvalósuló pedagógiai tevékenységről. Az eredmények alapján megfogalmazható, hogy a szakmai vezetők hangsúlyozták a pedagógia által kínált nevelési eszközökben rejlő lehetőségek kiaknázását.

Varga (2017) publikációjában labdarúgó edzők pedagógiai nézeteit foglalja össze a mester és tanítvány kapcsolatán keresztül. A cél, hogy bemutassa az utánpótláskorú labdarúgók edzőinek preferált gyermekképét, valamint véleményüket az elfogadott és elutasított sportolók tulajdonságairól. A kapott adatok alapján elmondható, hogy az edzők a fiatal labdarúgók viselkedésformái közül a fegyelmezetlenséget preferálták a legkevésbé.

\section{Cél}

Kutatásunk célja egy magyarországi kiemelt labdarúgó akadémián az edzők és a szülők véleményének tükrében bemutatni azt, hogy mely tényezők vannak hatással a tehetséggondozásban részt vevő labdarúgók személyiségének pozitív alakulására és sportolói karrierjének kiteljesedésére. A vizsgálat során három szférát érintettünk:

- a fiatal labdarúgók magatartásformái

- a renddel, napirenddel összefüggő tevékenységek

- az iskolai oktatáshoz kapcsolódó követelmények

\section{Módszer}

\section{Minta}

A vizsgálatot Magyarország egyik kiemelt akadémiáján végeztük el. A kutatás folyamán edzőket, négy különböző korosztályt (U-15, U-16, U-17 és U-19) képviselő utánpótláskorú labdarúgók szüleit szólítottunk meg (1. táblázat). Az adatfelvételi helyszínen az akadémiát irányító testület jóváhagyta a kutatáshoz tartozó etikai és módszertani ajánlásokat.

Az adatfelvétel az edzők esetében 2019 márciusában, hétköznap történt, a szülők otthon töltötték ki a kérdőívet.

A mintából az edzők nem hiányoztak, a szülők közül négyen nem éltek a válaszadás lehetőségével. Összesen 98 személy válaszait gyűjtöttük össze.

\begin{tabular}{|c|c|c|c|c|}
\hline diplomás edzők & $\begin{array}{c}\text { diploma nélküli } \\
\text { edzők }\end{array}$ & diplomás szülők & $\begin{array}{c}\text { diploma nélküli } \\
\text { szülők }\end{array}$ & $\Sigma$ \\
\hline 6 & 12 & 34 & 46 & 98 \\
\hline
\end{tabular}

1. táblázat. A vizsgálatban részt vevö személyek számának csoportonkénti megoszlása (Forrás: a Szerzö) 


\section{Eszközök}

A vizsgálat során az írásbeli kikérdezés módszerét alkalmaztuk. A kérdések az utánpótláskorú sportolók sporton túli viselkedés- és magatartásformáira irányulnak, melynek során arra derítünk fényt, hogy mely tényezőket tartják az edzők és a szülők meghatározónak a fiatal labdarúgók beválását és személyiségének fejlesztését befolyásoló tényezők közül.

A kérdőív 13 zárt jellegű kérdést tartalmazott. 1-től 4-ig terjedő attitűdskálán kellett meghatározni az edzőknek és a szülőknek, hogy mennyire értenek egyet az adott állítással: az 1-es érték jelentette a kérdéssel vagy meghatározással való teljes egyet nem értést, az 4-es érték pedig az állítással való teljes egyetértést.

\section{Eljárás}

Az adatok elemzéséhez az SPSS 25.0 statisztikai programot alkalmaztuk. A minta jellemzéséhez leíró statisztikát, a csoportok különbözőségeinek bemutatására varianciaanalízist (Post Hoc) alkalmaztunk. Szignifikancia szintnek az 5\%-os hibahatárt vettük alapul.

\section{Eredmények}

A fiatal labdarúgók személyiségét és pályafutását befolyásoló magatartással összefüggő tényezőket (2. táblázat) vizsgálva elmondható, hogy a négy alminta „Az edzővel szembeni tisztelettudó magatartás” ( $M=3,93 ; \mathrm{SD}=0,24)$ alskálát jellemezték nagyon magas pontszámmal, míg a legalacsonyabb értéket „Az iskolatársakkal szembeni tisztelettudó magatartás” $(\mathrm{M}=3,68 ; \mathrm{SD}=0,48)$ kapott. Nem találtunk szignifikáns különbséget a vizsgálatban szereplő személyek állításai között. 


\begin{tabular}{|c|c|c|c|c|c|c|c|}
\hline & 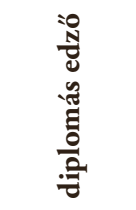 & 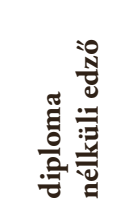 & 률 & 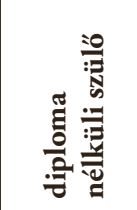 & $\Sigma$ & $\mathbf{F}$ & $\mathbf{p}$ \\
\hline & $\mathrm{M} \pm \mathrm{SD}$ & $\mathrm{M} \pm \mathrm{SD}$ & $\mathrm{M} \pm \mathrm{SD}$ & $\mathrm{M} \pm \mathrm{SD}$ & $\mathrm{M} \pm \mathrm{SD}$ & & \\
\hline $\begin{array}{l}\text { Az edzővel szem- } \\
\text { beni tisztelettudó } \\
\text { magatartás }\end{array}$ & $4,0 \pm 0,0$ & $3,91 \pm 0,28$ & $3,91 \pm 0,28$ & $3,95 \pm 0,2$ & $3,93 \pm 0,24$ & 0,38 & 0,767 \\
\hline $\begin{array}{l}\text { A csapattársakkal } \\
\text { szembeni tisztelet- } \\
\text { tudó magatartás }\end{array}$ & $4,0 \pm 0,0$ & $4,0 \pm 0,0$ & $3,82 \pm 0,38$ & $3,71 \pm 0,5$ & $3,80 \pm 0,42$ & 2,02 & 0,116 \\
\hline $\begin{array}{l}\text { Az egyesület egyéb } \\
\text { alkalmazottaival } \\
\text { szembeni tisztelet- } \\
\text { tudó magatartás }\end{array}$ & $3,5 \pm 0,83$ & $3,83 \pm 0,38$ & $3,82 \pm 0,38$ & $3,84 \pm 0,36$ & $3,81 \pm 041$ & 1,27 & 0,289 \\
\hline $\begin{array}{l}\text { A tanárokkal szem- } \\
\text { beni tisztelettudó } \\
\text { magatartás }\end{array}$ & $3,66 \pm 0,51$ & $3,75 \pm 0,45$ & $3,85 \pm 0,35$ & $3,87 \pm 0,34$ & $3,83 \pm 0,37$ & 0,77 & 0,512 \\
\hline $\begin{array}{l}\text { Az iskolatársakkal } \\
\text { szembeni tisztelet- } \\
\text { tudó magatartás }\end{array}$ & $3,5 \pm 0,54$ & $3,41 \pm 0,66$ & $3,79 \pm 0,41$ & $3,69 \pm 0,46$ & $3,68 \pm 0,48$ & 2,13 & 0,101 \\
\hline
\end{tabular}

Megjegyzés: Az alskálákon elért összpontszám terjedelme: $1-4 . p<0,05$.

2. táblázat. A magatartással összefüggö tényezök átlagai, szórásai és varianciaanalizisea négy alminta alapján (Forrás: a Szerzö)

A „rend, napirend”-hez kapcsolódó tényezők (3.táblázat) eredményei szerint a csoportok kiemelt jelentőséget tulajdonítanak az edzésen való pontos megjelenésnek $(M=3,83$; $\mathrm{SD}=0,39)$, viszont alacsony értékkel jellemezték „A kollégiumi szoba rendje, tisztasága” alskálát $(\mathrm{M}=3,20 ; \mathrm{SD}=0,67)$.

Az alminták között statisztikailag kimutatható különbséget két alskála esetében találtunk. A diplomával nem rendelkező edzők a legalacsonyabb pontszámmal véleményezték a „A kollégiumi szoba rendje, tisztasága” $(\mathrm{F}=4,801 ; \mathrm{p}=0,004)$ faktort, mely szignifikánsan tért el mindkét szülői csoport nézetétől. Az „A megfelelő időben a reggeli felkelés”-faktort tekintve egyaránt statisztikailag kimutatható különbség mutatkozott a diplomával nem rendelkező edzők és a szülői csoportok $(\mathrm{F}=4,139 ; \mathrm{p}=0,008)$, valamint a diplomával nem rendelkező szülők és mindkét edzői alminta véleményei között $(\mathrm{F}=4,139 ; \mathrm{p}=0,008)$. 


\begin{tabular}{|c|c|c|c|c|c|c|c|}
\hline & 胥 & 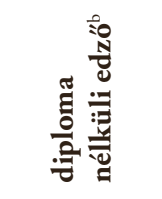 & 苞 & 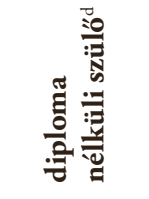 & $\Sigma$ & $\mathbf{F}$ & $\mathbf{p}$ \\
\hline & $\mathrm{M} \pm \mathrm{SD}$ & $\mathrm{M} \pm \mathrm{SD}$ & $\mathrm{M} \pm \mathrm{SD}$ & $\mathrm{M} \pm \mathrm{SD}$ & $\mathrm{M} \pm \mathrm{SD}$ & & \\
\hline $\begin{array}{l}\text { Az öltöző rendje, } \\
\text { tisztasága }\end{array}$ & $3,5 \pm 0,54$ & $3,41 \pm 0,79$ & $3,23 \pm 0,55$ & $3,34 \pm 0,6$ & $3,32 \pm 0,6$ & 0,52 & 0,669 \\
\hline $\begin{array}{l}\text { Az edzésen való } \\
\text { pontos megjelenés }\end{array}$ & $4,0 \pm 0,0$ & $3,75 \pm 0,45$ & $3,79 \pm 0,47$ & $3,87 \pm 0,34$ & $3,83 \pm 0,39$ & 0,75 & 0,523 \\
\hline $\begin{array}{l}\text { A kollégiumi szoba } \\
\text { rendje, tisztasága }\end{array}$ & $3,0 \pm 0,63$ & $2,66 \pm 0,77^{\mathrm{cd}}$ & $3,14 \pm 0,6^{b}$ & $3,41 \pm 0,61^{\mathrm{b}}$ & $3,20 \pm 0,67$ & 4,80 & 0,004 \\
\hline $\begin{array}{l}\text { A megfelelő időben } \\
\text { a reggeli felkelés }\end{array}$ & $2,83 \pm 0,75^{d}$ & $2,91 \pm 0,66^{\mathrm{cd}}$ & $3,38 \pm 0,6^{\mathrm{b}}$ & $3,5 \pm 0,62^{\mathrm{ab}}$ & $3,34 \pm 0,65$ & 4,13 & 0,008 \\
\hline $\begin{array}{l}\text { Az iskolában a pontos } \\
\text { megjelenés }\end{array}$ & $3,5 \pm 0,83$ & $3,41 \pm 0,79$ & $3,58 \pm 0,6$ & $3,73 \pm 0,49$ & $3,63 \pm 0,59$ & 1,17 & 0,325 \\
\hline A megfelelő napirend & $3,66 \pm 0,51$ & $3,5 \pm 0,52$ & $3,58 \pm 0,6$ & $3,63 \pm 0,53$ & $3,60 \pm 0,55$ & 0,20 & 0,891 \\
\hline
\end{tabular}

Megjegyzés: Az alskálákon elért összpontszám terjedelme: 1-4. p<0,05. A felsö indexek az átlagok páronkénti összehasonlitásának eredményeként kapott szignifikáns különbségeket jelzik az alminták között.

3. táblázat. A renddel, napirenddel összefüggö tényezök átlagai, szórásai és varianciaanalizise - a négy alminta alapján (Forrás: a Szerzö)

Az iskolai oktatást érintő két alskálát (4. táblázat) elemezve megállapítható, hogy az edzők és a szülők egyaránt alacsonyabb pontszámmal értékelték „Az iskolai tanulmányi követelmények azonosak legyenek a labdarúgók számára” $(\mathrm{M}=3,02 ; \mathrm{SD}=0,86))$ tényezőt. A diplomával nem rendelkező edzők szignifikánsan eltérő véleményt fogalmaztak meg a szülókkel szemben „Az iskolai érdemjegy a teljesítményt tükrözze a labdarúgók esetében is" $(\mathrm{F}=4,342 ; \mathrm{p}=0,007)$ faktor tekintetében. 


\begin{tabular}{|c|c|c|c|c|c|c|c|}
\hline & $\begin{array}{c}\text { diplomás } \\
\text { edzó }^{a}\end{array}$ & $\begin{array}{l}\text { diploma } \\
\text { nélküli } \\
\text { edzőb }^{b}\end{array}$ & $\begin{array}{l}\text { diplomás } \\
\text { szüllö }^{c}\end{array}$ & $\begin{array}{c}\text { diploma } \\
\text { nélküli } \\
\text { szülö }^{\mathrm{d}}\end{array}$ & $\Sigma$ & \multirow[t]{2}{*}{$\mathbf{F}$} & \multirow[t]{2}{*}{$\mathbf{p}$} \\
\hline & $\mathrm{M} \pm \mathrm{SD}$ & $\mathrm{M} \pm \mathrm{SD}$ & $\mathrm{M} \pm \mathrm{SD}$ & $\mathrm{M} \pm \mathrm{SD}$ & $\mathrm{M} \pm \mathrm{SD}$ & & \\
\hline $\begin{array}{l}\text { Az iskolai tanulmá- } \\
\text { nyi követelmények } \\
\text { azonosak legyenek } \\
\text { a labdarúgók számára }\end{array}$ & $3,16 \pm 1,16$ & $2,58 \pm 0,66$ & $2,94 \pm 0,81$ & $3,17 \pm 0,87$ & $3,02 \pm 0,86$ & 1,70 & 0,171 \\
\hline $\begin{array}{l}\text { Az iskolai érdemjegy } \\
\text { a teljesítményt tükrö- } \\
\text { zze a labdarúgók } \\
\text { esetében is }\end{array}$ & $3,0 \pm 1,09$ & $2,41 \pm 0,66^{\mathrm{cd}}$ & $3,08 \pm 0,75^{\mathrm{b}}$ & $3,32 \pm 0,79^{b}$ & $3,11 \pm 0,82$ & 4,34 & 0,007 \\
\hline
\end{tabular}

Megjegyzés: Az alskálákon elért összpontszám terjedelme: 1-4. $p<0,05$. A felsö indexek az átlagok páronkénti összehasonlitásának eredményeként kapott szignifikáns különbségeket jelzik az alminták között.

4. táblázat. Az iskolai oktatással összefüggő tényezők átlagai, szórásai és varianciaanalízise - a négy alminta alapján (Forrás: a Szerzö)

\section{Diszkusszió, összegzés}

A kutatásban a labdarúgó akadémián dolgozó edzők és a fiatal játékosok szülei véleményére alapozva olyan tényezőket vizsgáltunk, melyek pozitív hatást gyakorolhatnak utánpótláskorú labdarúgók személyiségfejlődésére, ezáltal segítve teljesítményük optimumának elérését.

A vizsgálat eredményei alapján megállapítható, hogy a diplomával rendelkező és diplomával nem rendelkező edzők, valamint a szülők hasonló és eltérő nézeteket egyaránt megfogalmaznak az utánpótláskorú labdarúgó személyiségét és pályafutását befolyásoló tényezők tekintetében. Feltételezhető okként megemlíthetjük az edzők és a szülők között fellelhető iskolázottságbeli különbséget. Érdemes lehet az edzők és a szülők számára az iskolai végzettségtől függetlenül nonformális tanulási mód alkalmazásával bővíteni a gyerekek személyiségfejlesztéssel kapcsolatos ismereteiket. Elmondható, hogy szignifikáns különbség három tényezőt érintve hét esetben mutatkozott meg a négy alminta összehasonlítása során.

A magatartáshoz köthető állításokat tekintve a vizsgálatban részt vevő személyek kiemelten fontosnak tekintik, hogy a gyerekek tisztelettudó magatartást tanúsítsanak edzőik felé, míg legkisebb jelentőséget az iskolatársakkal szembeni tisztelettudó magatartásnak tulajdonítanak. Az itt elemzésre került alskálák esetében nem található statisztikailag kimutatható különbség.

Mindkét edzői és szülői csoport kiemeli az edzésen való pontos megjelenés súlyát, azonban a kollégiumi szoba rendjét, tisztaságát a legkevésbé vélték hangsúlyosnak. Az utóbbi alskála alacsony értékének ellenére a szülői csoportok egyértelmüen fontosabbnak vélik a szobarendet, valamint a reggeli felkelés jelentőségét a diplomával nem rendelkező edzőkkel szemben. 
Az iskolai oktatáshoz kapcsolódó két kérdés közül „Az iskolai tanulmányi követelmények azonosak legyenek a labdarúgók számára” alskála kapta az alacsonyabb értéket az edzőktől és szülőktől. A szülőkkel ellentétben a diplomával nem rendelkező edzők gondolják úgy, hogy a fiatal labdarúgók esetében nem feltétlenül kell tükröznie az érdemjegynek a tanulás során mutatott teljesítményt. Valószínűsíthető, hogy a még diplomaszerzés előtt álló edzők pedagógiai ismeretei elmaradnak a magasabb végzettségü kollégáikétól, ezáltal feltételezhető, hogy a sporttal felerősített nevelő hatás jelentősége még alig ismert előttük.

A nemzetközi szintü eredményekhez nem elég egy-egy motoros adottság magas szintü megléte, egyéb személyi faktorok is komoly hatással vannak a beválás folyamatára (Révész, Géczi, Bognár \& Tóth, 2005). A fiatal sportolókkal foglalkozó szakemberekben tudatosulnia kell, hogy az iskolai oktatást a sportolói tevékenység és a nevelés területeivel azonos szinten kell kezelniük, amelyek befolyással bírnak az utánpótláskorú sportolók fejlődésére (Kiss \& Bognár, 2018).

Kevésbé ismert tény a sportszakemberek előtt, hogy az erkölcsi magatartásformák összetevőinek (pl.: akarat, alázat, erőfeszítés, kitartás) fejlesztése nemcsak a sporttevékenység során lehetséges, hanem egyéb sporton túli területek, mint a nevelési és oktatási intézmények, vagy a családi környezet egyaránt alkalmat kínálnak a folyamat megvalósítására.

Ismereteink szélesítése és a statisztikai erő növelése érdekében érdemes ebben a témában további adatok gyűjtése egyéb hazai és határon túli magyar nemzetiségű gyerekeket foglalkoztató akadémiák bevonása révén.

\section{Felhasznált irodalom:}

Anshel, M.H. (2003). Sport psychology: From theory to practice. San Francisco, Benjamin Cummings.

Bábosik, I. (2004). Neveléselmélet. Budapest, Osiris Kiadó.

Biróné, Nagy E. (szerk.) (2004). Sportpedagógia. Kézikönyv a testnevelés és sport pedagógiai kérdéseinek tanulmányozásához. Budapest-Pécs, Dialóg Campus Kiadó.

Bognár J., Trzaskoma-Bicsérdy G., Révész L., Géczi G. (2006). A szülők szerepe a sporttehetség-gondozásban. Kalokagathia, 44, 1-2. pp. 86-95.

Czeizel, E. (1997). Sors és tehetség. Budapest, FITT IMAGE és a Minerva Kiadó.

Csáki, I., Bognár, J., Révész, L., \& Géczi, G. (2013) Elméletek és gyakorlatok a tehetséges labdarúgó kiválasztásához és beválásához. Magyar Sporttudományi Szemle, 14: 1 (53) $12-18$.

Fügedi, B., Bognár, J., Kovács, T., L, (2019). A szülői minta szerepe a sportolási szokásokban és a testnevelés megítélésében. Az Eszterházy Károly Egyetem tudományos 
közleményei (46. köt.). Tanulmányok a sporttudomány köréből = Acta Universitatis de Carolo Eszterházy Nominatae. Sectio Sport, 46., 47-55.

https://doi.org/10.33040/ActaUnivEszterhazySport.2019.1.47

Gombocz, J. (2004). A testnevelő tanár és az edző pedagógiai szerepe. In: Biróné, Nagy

E. (szerk.) Sportpedagógia. Kézikönyv a testnevelés és sport pedagógiai kérdéseinek tanulmányozásához. Budapest-Pécs, Dialóg Campus Kiadó. 147-171.

Gombocz, J. (2010). Sport és nevelés. Keszthely, Balaton Akadémia Kiadó.

Kay, T. (2004). The family factor in sport: A review of family factors affecting sports participation. Driving up participation: The challenge for sport. Loughborough University

Kelemen, L. (1984). Pedagógiai pszichológia. Budapest, Tankönyvkiadó.

Kiss, Z., Bognár, J. (2018). Fiatal labdarúgók beválását befolyásoló nevelési tényezők: egy kiemelt akadémia döntéseinek tanulságai. In: Endrődy-Nagy O., Fehérvári A. (szerk.), Innováció, kutatás, pedagógusok. Budapest, Magyar Nevelés- és Oktatáskutatók Egyesülete. 103-119.

Kozéki, B. (1983). A fegyelmezett személyiség kialakitása. Budapest, Tankönyvkiadó.

Kozéki, B. (1987). Moralitás, jellemfejlesztés. Budapest, Tankönyvkiadó.

Kozma, T. (1994). Bevezetés a nevelésszociológiába. Budapest, Nemzeti Tankönyvkiadó.

Kron, F. W. (2003) Pedagógia. Budapest, Osiris Kiadó.

Nagy, S. (2001). Együtt a gyerekekért. Budapest, Animula Kiadó.

Paulsen, F. (1972). Az akarat nevelése. Budapest, Tankönyvkiadó.

Rábai, D. (2018). Lila-fehér mezben. Egy fővárosi és egy vidéki labdarúgó akadémia neveléstudományi megközelítésű vizsgálata, összehasonlítása. Iskolakultúra. 3-4, 53-63.

Révész, L., Géczi, G., Bognár, J., \& Tóth, L. (2005). A sporttehetség megközelítési módjai. Magyar Edzö: Módszertani és továbbképzö folyóirat 8. 4. 5-7.

Révész, L., Bognár, J., Csáki, I., \& Trzaskoma-Bicsérdy, G. (2013). Az edző-sportoló kapcsolat vizsgálata az úszás sportágban. Magyar Pedagógia 113. 1. 53-72.

Vannai, J. (2019). Gyermeksport. Budapest, Krea-Fitt Kft.

Varga, D. (2017). Képben a gyermekkép: Labdarúgó edzők nézetei a mester és utánpótláskorú tanítványai kapcsolatáról. Magyar Sporttudományi Szemle, 71, 46-51.

Zrinszky, L. (2006) Neveléselmélet. Budapest, Műszaki Könyvkiadó Kft. 14. 